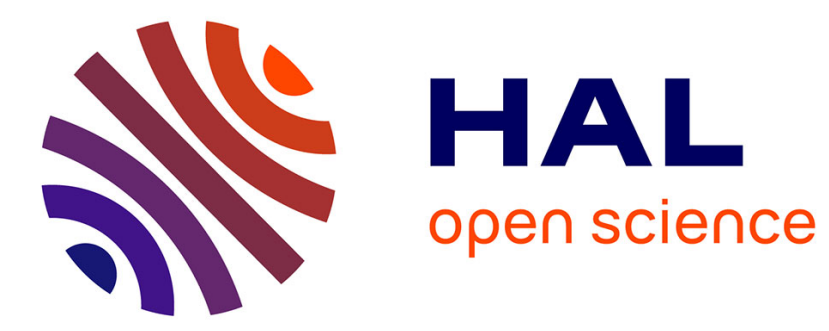

\title{
Thixoforming of Steel: New Tools Conception to Analyse Thermal Exchanges and Strain Rate Effects
}

Pierre Cezard, Régis Bigot, Eric Becker, Stéphane Mathieu, Jean-Christophe Pierret, Ahmed Rassili

\section{- To cite this version:}

Pierre Cezard, Régis Bigot, Eric Becker, Stéphane Mathieu, Jean-Christophe Pierret, et al.. Thixoforming of Steel: New Tools Conception to Analyse Thermal Exchanges and Strain Rate Effects. 10th ESAFORM Conference on Material Forming, Apr 2007, Zaragoza, Spain. pp.1155-1160, 10.1063/1.2729670 . hal-01090480

\section{HAL Id: hal-01090480 \\ https://hal.science/hal-01090480}

Submitted on 3 Dec 2014

HAL is a multi-disciplinary open access archive for the deposit and dissemination of scientific research documents, whether they are published or not. The documents may come from teaching and research institutions in France or abroad, or from public or private research centers.
L'archive ouverte pluridisciplinaire HAL, est destinée au dépôt et à la diffusion de documents scientifiques de niveau recherche, publiés ou non, émanant des établissements d'enseignement et de recherche français ou étrangers, des laboratoires publics ou privés. 


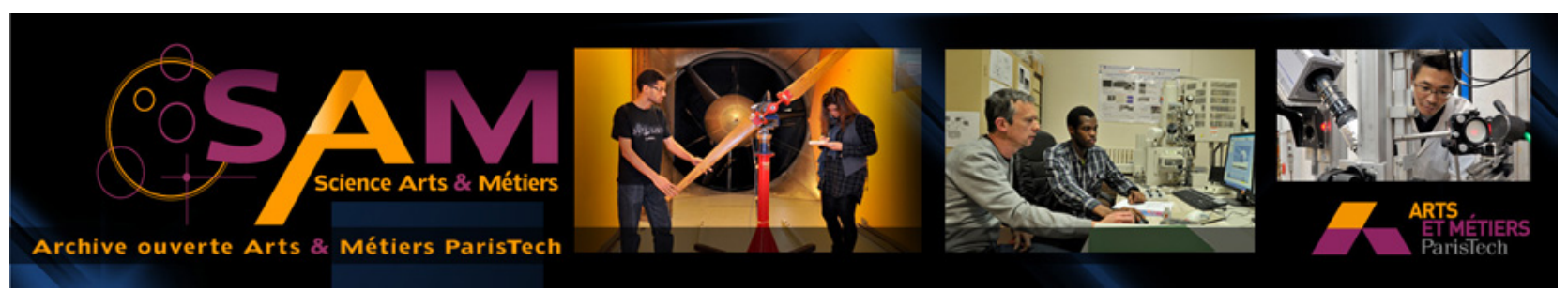

\section{Science Arts \& Métiers (SAM)}

is an open access repository that collects the work of Arts et Métiers ParisTech researchers and makes it freely available over the web where possible.

This is an author-deposited version published in: http://sam.ensam.eu

Handle ID: .http://hdl.handle.net/10985/9050

\section{To cite this version :}

Pierre CEZARD, Régis BIGOT, Eric BECKER, Stéphane MATHIEU, Jean-Christophe PIERRET, Ahmed RASSILI - Thixoforming of Steel: New Tools Conception to Analyse Thermal Exchanges and Strain Rate Effects - In: 10th ESAFORM Conference on Material Forming, Spain, 2007-04-18 - AIP COnference Proceedings of the 10th ESAFORM - 2007 


\title{
Thixoforming of Steel: New Tools Conception to Analyse Thermal Exchanges and Strain Rate Effects
}

\author{
P.Cezard ${ }^{1}$, R.Bigot ${ }^{1}$, E.Becker ${ }^{1}$, S.Mathieu ${ }^{1}$, J.C.Pierret ${ }^{2}$ and A.Rassili ${ }^{2}$ \\ ${ }^{I}$ LGIPM-ENSAM - 4, Rue Augustin Fresnel, 57070 Metz Technopôle-France \\ e-mail: regis.bigot@metz.ensam.fr \\ ${ }^{2} U L G$ - place du 20-Août-9 à B-4000 Liège - Belgique
}

\begin{abstract}
Through different papers [1,2], authors shown that the influence of thermal exchanges was a first order parameter on the semi-solid steel behaviour, and certainly for every semi-solid metallic materials. These thermal exchanges hide other parameters effect like, for example, the strain rate influence. This paper tries to determine the influence of these two parameters by using a new extrusion device on a hydraulic press. This new tools conception annihilated the influence of the decrease of the punch speed before stopping and permitted to have a constant speed during the experiment. This work also deals with the homogeneous flow during thixoforming of steel and shows the importance to couple initial temperature of the slug with punch speed. This paper presents different conditions which permitted to have a homogeneous flow by keeping a low load.
\end{abstract}

Keywords: Thixoforming of steel, Thermal effects, Strain rate, Tools conception, Semi-solid flow

PACS: 83.50.Uv

\section{INTRODUCTION}

The focus of semi-solid researches is nowadays on thixoforging of high melting alloys like steel. Different ways are used to study this subject $[4,5,6,7]$. For few years, we developed experimental devices which permitted to study the behaviour of semisolid steel through rheological tests. Several parameters, like strain rate, had been studied with these experiments. These works shown that the influence of thermal exchanges was a first order parameter on the steel semi-solid behaviour $[1,2,3]$.

During these works, collaborations had been developed with different laboratories and particularly with the University of Liege (ULG). An important campaign of experimental tests has been realized on their hydraulic press. To perform these experiments, a new extrusion tool has been designed. The aim of this campaign was to study the influence of two parameters: initial temperature of the slug, and punch speed. The load need to extrude the part and the geometry of the final part were used

CP907, $10^{\text {th }}$ ESAFORM Conference on Material Forming, edited by E. Cueto and F. Chinesta ๑ 2007 American Institute of Physics 978-0-7354-0414-4/07/\$23.00 
to compare the experiments. The goal was to have a correct geometry of the part (without cracks for example) with the lower load.

This paper presents the tools design and the experiments facilities. It also shows the principal results and discussed about the necessity to couple parameters together.

\section{EXPERIMENTAL DEVICES}

This part presents the conditions used to realised the experiments, the semi-solid material, the extrusion principle, and the tools conception including a damping system.

\section{Semi-Solid Material}

A classical C38 low alloy steel grade was used for this campaign. The slugs are obtained by cutting of rolling bars. Their dimensions are $30 \mathrm{~mm}$ diameter and $45 \mathrm{~mm}$ high. Table 1. shows the chemical composition (by mass) of this steel grade.

TABLE 1. C38 chemical composition $\left(10^{-3} \%\right)$.

\begin{tabular}{llcccccccc}
\hline $\mathbf{C}$ & $\mathbf{M n}$ & $\mathbf{P}$ & $\mathbf{S}$ & $\mathbf{S i}$ & $\mathbf{A l}$ & $\mathbf{N}$ & $\mathbf{N i}$ & $\mathbf{C r}$ & $\mathbf{C u}$ \\
\hline 418 & 751 & 10 & 21 & 198 & 21 & 65 & 77 & 144 & 133 \\
\hline
\end{tabular}

The semi-solid domain determined by differential scanning calorimetry (DSC) is presented on figure 1 . The liquid fraction versus temperature of the slug is obtained with a heating speed of $20^{\circ} \mathrm{C}$ per minute, which is slower than the experimental heating speed.

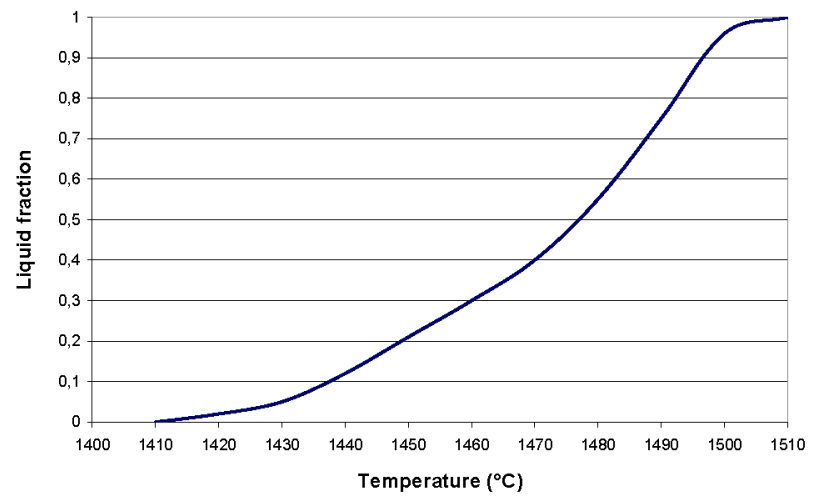

Figure 1. Liquid fraction versus temperature obtained by DSC.

This result should be take into account with precautions. The real liquid fraction in the slug could be different due to the higher heating speed and the particular conditions of a different scanning calorimetry test (size of the sample, etc). 


\section{Extrusion Test}

The extrusion test consists to push the slug through a funnel to reduce its diameter. The figure 2 shows the principle of the test. For this campaign, slugs were $30 \mathrm{~mm}$ diameter and $45 \mathrm{~mm}$ high. The dimensions of the filling die were $40 \mathrm{~mm}$ diameter at the start and $12 \mathrm{~mm}$ diameter at the end. This geometry was choose to complete precedent works $[2,4,8]$.

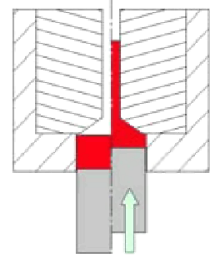

Figure 2. Principle of an extrusion test.

\section{Conception of the Tools}

It is important to notice that the heating device is integrate to the tools. An induction heating device is used and the filling dies are design to pass through the inductor (Figure 3). This conception allowed to avoid a transfer of the slug from the heating device to the forming tools. The extrusion test takes place at the end of the heating without time out. Materials used are tool steel (X38CrMoV5) for the filling die and ceramic alloys for the piston.

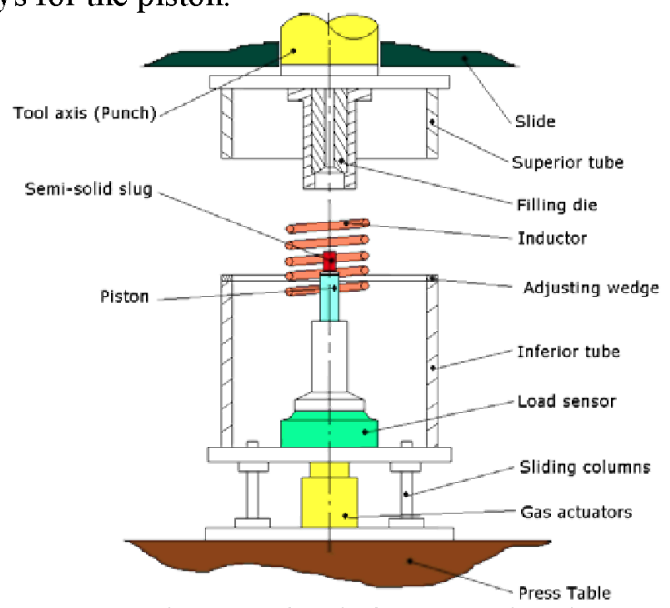

Figure 3. Complete extrusion device mounted on the press.

A damping system is also integrated in the tool set-up. Indeed, the tool axis of the press stopped with a decreasing speed. To keep a constant forming speed it is important to "absorb" this decreasing phase without deformation of the slug. A damping device is placed under active tools to move when the superior tube arrive in contact with the inferior tube. It is composed by four gas actuators, and four sliding columns. 


\section{EXPERIMENTAL RESULTS}

This part gives the principal results of the experimental campaign. The influence of each parameter is described through load curves or maximum load, and geometry.

\section{Influence of the Tool Axis Speed}

The first parameter studied was the influence of the tool axis speed. A heating cycle giving a temperature of the slug of $1451^{\circ} \mathrm{C}$ (approximately 0,3 liquid fraction) has been used for each experiment. The filling die is cold and cooling after each experiment. The die surface is ground and a ceramic based lubricant is pulverised on it. Three speeds were studied: $40 \mathrm{~mm} / \mathrm{s}, 100 \mathrm{~mm} / \mathrm{s}, 215 \mathrm{~mm} / \mathrm{s}$. The figure 4 shows the load results obtained during this campaign. The maximum loads to do the part for each speed are compared.

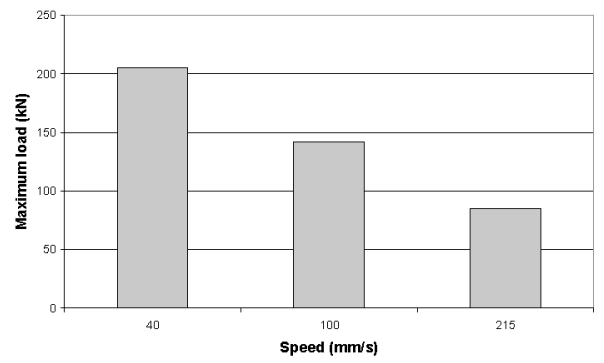

Figure 4. Maximum load to obtain the part for each speed.

An important decrease of the load is recorded when the speed increase. The maximum load when the speed is $215 \mathrm{~mm} / \mathrm{s}$ is less than half value of the load when the speed is $40 \mathrm{~mm} / \mathrm{s}$. Concerning the geometries, there are not many differences between experiments. The flow is very heterogeneous with liquid ejection and surface solidification.

Changing the punch speed modify two things. First, it changes the strain rate during deformation. According to literature $[9,10,11]$, the strain rate controls a part of the disagglomeration of the solid skeleton formed by solid particles. Increase the punch speed could permit to accelerate disagglomeration of the semi-solid microstructure and decrease the viscosity. But, modify the tool axis speed change also the forming time and by that way, the thermal exchanges. When the forming is faster, the slug temperature stay hotter and the liquid fraction higher. The viscosity should be lower due to these effects and that also goes in the results ways.

\section{Influence of the Initial Temperature of the Slug}

The second parameter studied was the initial temperature of the slug. The tool axis speed used was $215 \mathrm{~mm} / \mathrm{s}$ to minimize the load (see firsts results). The filling die is cooling between each experiment. Five temperatures between $1429^{\circ} \mathrm{C}$ to $1451^{\circ} \mathrm{C}$ were 
used for the slugs (approximately between 0,1 and 0,3 liquid fraction). The figure 4 shows the part obtained with these temperatures.

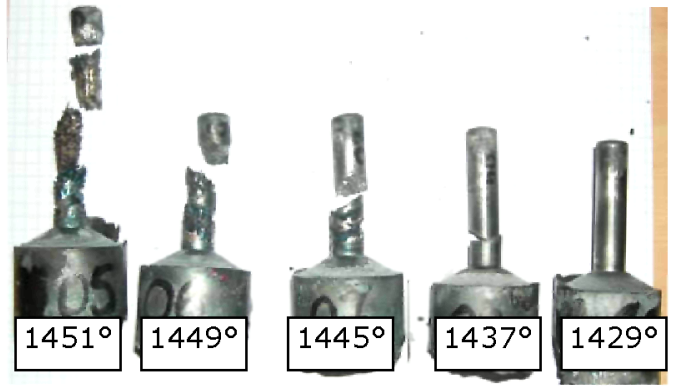

Figure 4. Parts obtained by decreasing the initial temperature of the slug.

The figure 4 shows that the lower the temperature is, the better the flow is. These results show that it exists a limit which gives a good flow. The figure 5 presents the maximum load recorded for each temperature.

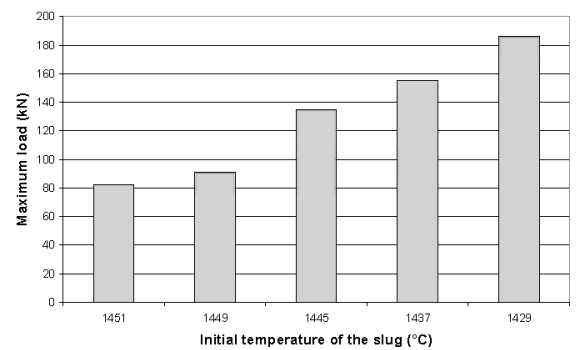

Figure 5. Maximum load to obtained part by changing initial temperature of the slug

Figure 5 shows that the load increases when the temperature decreases but the load stays acceptable.

When the temperature is higher, the liquid fraction is also higher, so the consistency of the semi-solid should be lower. This effect explains these results. Moreover, when the liquid fraction decreases, the solid skeleton should be more connected, and the liquid ejection doesn't happen. That could explain the limit temperature which is certainly a liquid fraction limit.

\section{DISCUSSION}

These results show the importance of the punch speed and the initial temperature. Through these two parameters took place complex phenomena, like the evolution of liquid fraction or the evolution of the solid skeleton with disagglomeration or solidification/agglomeration phenomena.

An important result is presented on figure 6, where two different flows are obtained for the same load $(\sim 200 \mathrm{kN})$ by changing initial temperature and punch speed. 


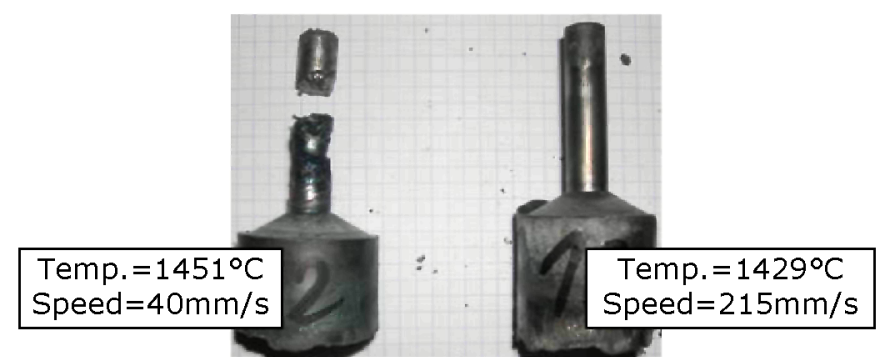

Figure 6. Two parts obtained with the same force $(200 \mathrm{kN})$

This result shows that it is possible to obtain a homogeneous flow without increasing the load by choosing an appropriate punch speed. It is certainly possible to go further in that way by limiting thermal exchanges with the tools. For example, other paper shows that the heating of the tools allowed lower load forming $[1,2]$.

\section{CONCLUSIONS}

These results show the importance to couple different parameters to optimize the thixoforming process. To obtain a low load and a homogeneous flow, it is possible to choose adequate temperature and punch speed. For the speed parameter, the difficulty is to evaluate the influence of the thermal exchanges compare to the influence of disagglomeration of the solid skeleton due to a higher strain rate. Numerical simulations should help to identify the role of each effect. Finally, this campaign reinforced the last results on the influence of thermal effect, and confirm the necessary works on this subject for high fusion point materials like steel.

\section{REFERENCES}

1. R. Bigot, V. Favier and C. Rouff, "Characterisation of semi-solid material mechanical behaviour by indentation test", Journal of Materials Processing Technology, Vol. 160, Issue 1, 2005, pp. 43-53

2. P. Cezard, R. Bigot, V. Favier, M. Robelet, "Thixoforming of Steel - Influence of thermal parameters", Solid State Phenomena, Vol. 116-117, 2006, pp. 721-724

3. Lugscheider E., Hornig Th., Neuschütz D., Kyrylov O., Prange R., Telle R., Schmidt R., "MaterialConcepts for Dies for SSM-forming of steel", Proc. of the 6th Int. Conf. on Semi-Solid Processing of Alloys and Composites, Turin, Italy, 2000, ISBN 88-86259-18-2, pp. 587-592

4. M.Z. Omar, E.J. Palmiere, A.A. Howe, H.V. Atkinson, P. Kapranos, "Thixoforming of a high performance HP9/4/30 steel", Mat. Sci. andEng. A, 395, Issues 1-2, pp.53-61

5. A. Rassili, M. Robelet, D. Fischer, "Series production of thixoformed steel parts", Proc. of the 9th ESAFORM Conf. on material forming, Glasgow, United kingdom, 2006, pp.819-822

6. H. Shimahara, R. Kopp, "Investigations of basic data for the semi-solid forging of steels", Proc. of the 8th Int. Conf. on Semi-Solid Processing of Alloys and Composites, Limassol, Cyprus, 2004

7. M. Modigell, L. Pape, M. Hufschmidt, "Rheological properties of semi-solid metallic alloys", Proc. of the 8th ESAFORM Conf. on material forming, Cluj Napoca, Romania, 2005, 2, pp.1111-1114

8. P. Cezard, "Impact des effets thermiques sur le comportement du matériau lors de la mise en forme des aciers à l'état semi-solide : Analyses expérimentale et numérique », Ph.D. Thesis, ENSAM, 2006.

9. Z. Fan, "Semisolid metal processing", Int. Mat. Rev., 47-2, 2002, pp. 49-85

10. P. Kumar, C. Martin, S.B. Brown, "Shear rate thickening behavior of semisolid slurries", Metall. Trans. A, 24, 1993, pp.1107-1116

11. D.H. Kirkwood, "Semisolid metal processing", Int. Mat. Rev., 39, 1994, pp.173-189 